\title{
PENGEMBANGAN MEDIA PEMBELAJARAN BERBASIS APLIKASI ANDROID PADA PROGRAM STUDI ILMU PERPUSTAKAAN DAN INFORMASI UNIVERSITAS ISLAM NEGERI SULTHAN THAHA SAIFUDDIN JAMBI
}

\author{
Sigit Hartono ${ }^{1}$, Ade Saputra ${ }^{2}$ \\ Fakultas Syariah dan Fakultas Adab dan Humaniora-UIN STS Jambi \\ Corresponding Author: hartonosigit@uinjambi.ac.id
}

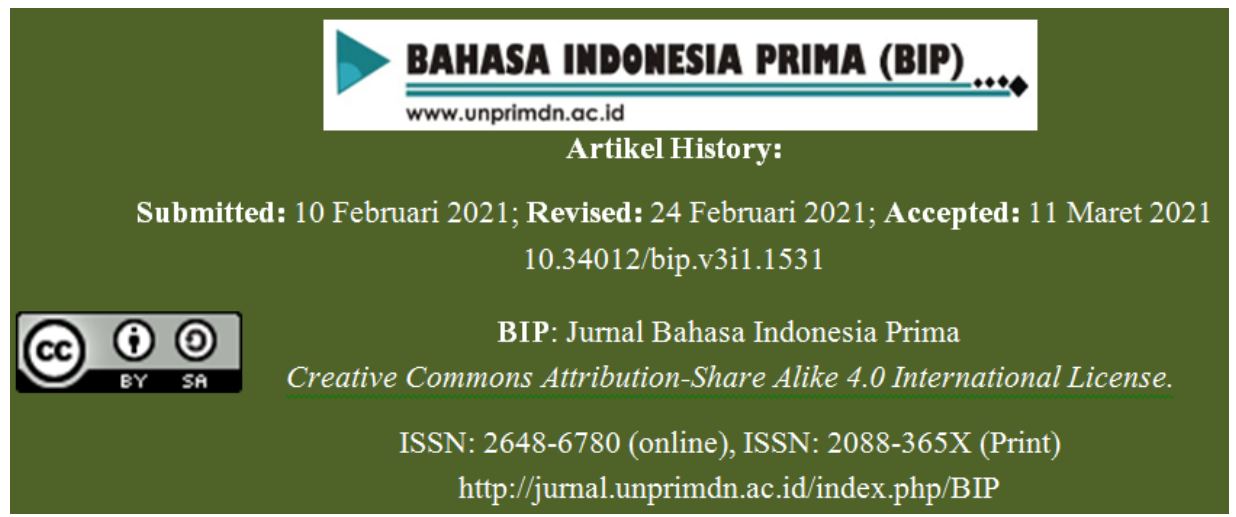

\begin{abstract}
Abstrak-Media pembelajaran merupakan salah satu factor penunjang yang penting dalam mencapai tujuan pembelajaran. Media pembelajaran seharusnya memiliki tampilan menarik, mudah digunakan, serta dapat digunakan kapan saja dan di mana saja sehingga dapat merangsang minat belajar mahasiswa. Tujuan dari penelitian ini adalah mengembangkan media pembelajaran berbentuk aplikasi android di Program Studi Ilmu Perpustakaan. Penelitian ini merupakan penelitian research and design yang terdiri dari tiga tahap yaitu analisis produk, pengembangan produk, dan uji coba. Pada tahapan uji coba ala tukur yang digunakan menggunakan kuesioner. Penilaian kelayakan aplikasi dilakukan pada satu orang ahli media, satu orang ahli materi, dan uji coba pada 40 orang mahasiswa. Penilaian kelayakan aplikasi dan uji coba menggunakan kuesioner yang selanjutnya dianalisis secara deskriptif kuantitatif. Hasil penelitian didapatkan media pembelajaran berbasis aplikasi android sangat layak untuk digunakan dengan hasil skor penilaian dari ahli media 83,92\%, skor penilaian dari ahli materi $84,21 \%$, dan hasil uji coba yang dilakukan pada 40 orang mahasiswa mendapatkan skor 81,49\%. Diharapkan aplikasi ini dapat digunakan sebagai salah satu media pembelajaran. Selain itu diharapkan dilakukan pengembangan lebih lanjut agar aplikasi ini dapat digunakan di berbagai platform tidak sebatas pada android saja.
\end{abstract}

Kata Kunci: Media Pembelajaran, Aplikasi, Android

\section{A. Pendahuluan}

Perkembangan teknologi masa kini tidak lepas dari adanya penemuan teknologi terdahulu, yang mana teknologi telah ada sejak zaman terdahulu. Teknologi berkembang secara drastis dan terus menerus berevolusi hingga sekarang, mulai dari penciptaan obyek-obyek hingga teknik yang dapat membantu manusia dalam melakukan pekerjaan agar lebih efektif dan efisien.
Dalam dunia pendidikan, proses belajar mengajar melibatkan tenaga pendidik, mahasiswa, serta lingkungan pembelajaran. Dimana kesemua aspek tersebut saling mempengaruhi satu sama lain untuk mencapai tujuan pembelajaran. Di samping ketiga aspek tersebut, media pembelajaran merupakan salah satu faktor penunjang untuk mencapai tujuan pembelajaran tersebut (Hardianto, 2005).

Media pembelajaran yang biasa digunakan di institusi pendidikan seperti 
text book dan powerpoint. Namun, penggunaan textbook cenderung kurang praktis dan kurang menarik minat mahasiswa. Bahan cetak yang tebal mungkin dapat membosankan dan mematikan minat siswa untuk membacanya apabila jilidan dan kertas jelek. Selain itu, buku cetak akan mudah rusak dan sobek (Daryanto, 2010). Hal ini tentu akan berdampak pada minat belajar dari peserta didik. Oleh karena itu, dalam meningkatkan minat peserta didik dalam pembelajaran maka diperlukan pembaharuan dalam media pembelajaran. Dimana media pembelajaran yang dibutuhkan yaitu media pembelajaran yang memiliki tampilan menarik, mudah untuk digunakan, dan dapat digunakan di mana saja dan kapan saja.

Kemajuan teknologi saat ini mendukung perkembangan media pembelajaran. Media pembelajaran kini tidak hanya sebatas buku saja. Akan tetapi, media pembelajaran dapat diakses di komputer/laptop khususnya yang berbasis audiovisual seperti video maupun film. Media pembelajaran juga dapat diakses melalui handphone atau biasa disebut dengan aplikasi pembelajaran dan permainan edukasi(Purnama, Sesunan, \& Ertikanto, 2017).

Dewasa ini perkembangan teknologi handphone sangat pesat. Masyarakat dapat dengan mudah mendapatkannya mengingat harganya yang cukup terjangkau. Perkembangan handphone khususnya ponsel pintar atau yang biasa disebut dengan smartphone sangat mendukung dalam pengembangan media pembelajaran. Adapun sistem operasi yang dimiliki oleh smartphone salah satunya adalah sistem operasi android. Mayoritas smartphone tersebut menggunakan sistem operasi android. Hasil penelitian Nugroho \& Purwandari (2016)menunjukkan bahwa aplikasi pembelajaran dapat dijalankan pada smartphone dan mempermudah pengguna untuk dapat belajar melalui smartphone masing-masing. Selain itu, dengan adanya aplikasi ini memudahkan dalam penyampaian materi dan pelaksanaan ujian. Penelitian lain yang dilakukan oleh Amin \& Mayasari (2015) didapatkan hasil penggunaan media pembelajaran berbentuk aplikasi android lebih efektif dibandingkan dengan pembelajaran tanpa menggunakan aplikasi android pada smartphone.

Media pembelajaran dalam wujud aplikasi android memiliki sejumlah keunggulan yaitu memudahkan peserta didik/mahasiswa untuk belajar tidak hanya terbatas di dalam kelas saja. Akan tetapi, materi dapat diakses dimanapun dan kapanpun. Selain itu, dengan adanya media pembelajaran melalui aplikasi android ini, dengan bentuknya yang dinamis dapat meningkatkan minat dan motivasi mahasiswa. Namun demikian, media pembelajaran berbasis android juga memiliki sejumlah kelemahan seperti halnya aplikasi android bergantung pada ketahanan baterai dan juga penggunaan internet.

Berdasarkan hasil observasi yang dilakukan di Program Studi Ilmu Perpustakaan dan Informasi Fakultas Adab Humaniora UIN Sultan Thaha Syaifuddin Jambi didapatkan bahwa mayoritas mahasiswa memiliki smartphone. Akan tetapi, pemanfaatan smartphone oleh mahasiswa tersebut belum maksimal. Berdasarkan hasil wawancara dengan beberapa mahasiswa di Prodi Ilmu Perpustakaan dan Informasi mahasiswa memanfaatkan smartphone hanya untuk media sosial dan hanya sesekali untuk mengakses hal-hal yang terkait dengan materi kuliah. Selain itu Prodi Ilmu Perpustakaan dan Informasi UIN STS Jambi sendiri belum memiliki aplikasi berbasis android yang mendukung kegiatan pembelajaran.

Berdasarkan uraian di atas peneliti merasa tertarik untuk melakukan penelitian yang berjudul Pengembangan Aplikasi Android Sebagai Media Pembelajaran Pada Program Studi Ilmu Perpustakaan dan Informasi Fakultas Adab dan 
Humaniora UIN Sultan Thaha Syaifuddin Jambi.

\section{B. Metode}

Penelitian ini menggunakan desain penelitian model pengembangan dari Borg \& Gall (2005) yang telah dimodifikasi. Dalam penelitian ini tahapan pengembangan meliputi tiga tahap diantaranya analisis produk, pengembangan produk awal, dan tahapan uji coba yang dilakukan pada ahli media, ahli materi, dan kepada 40 orang mahasiswa. Dalam penelitian ini validasi ahli media dilakukan oleh Dosen Sistem Informasi, sedangkan ahli materi merupakan Dosen Prodi Ilmu Perpustakaan dan Informasi UIN STS Jambi. Teknik pengumpulan data menggunakan kuesioner yang dianalisis secara kuantitatif. Penilaian kuesioner menggunakan skala likert 1 sampai dengan 4 dimana skor $1=$ tidak setuju, $2=$ kurang setuju, $3=$ setuju, dan $4=$ sangat setuju. Selanjutnya total skor tersebutakan dikonversikan sehingga didapatkan persentase penilaian kelayakan produk dengan rentang nilai $76 \%-100 \%=$ sangat layak, $50 \%-75 \%=$ layak, $26 \%-50 \%=$ cukup, dan $<26 \%=$ kuranglayak (Widyoko, 2011).

\section{Hasil dan Pembahasan}

\section{Analisis produk yang dikembangkan}

Pada analisis produk dilakukan analisis konsep, analisis desain, dan mengumpulkan materi. Peneliti merancang media pembelajaran yang dapat memudahkan mahasiswa dalam mengakses materi perkuliahan. Materi pembelajaran yang dimuat dalam penelitian ini mengenai pangkalan data untuk lembaga informasi.

Setelah dirumuskan konsep produk tersebut, dilanjutkan dengan analisis desain. Dalam analisis desain peneliti merancang story board untuk aplikasi tersebut. Peneliti merancang beberapa menu yang akan digunakan pada aplikasi. Seperti menu pendaftaran akun, log-in, kelas, dan menu kuis.
Tahap terakhir dari analisis produk yaitu mengumpulkan materi. Pada penelitian ini, peneliti merancang dan menyusun materi perkuliahan serta soal beserta jawaban yang akan dimasukkan ke dalam menu kuis.

\section{Pengembangan Produk}

1. Tampilan Awal

Tampilan awal aplikasi memuat Logo dan Institusi UIN Jambi.

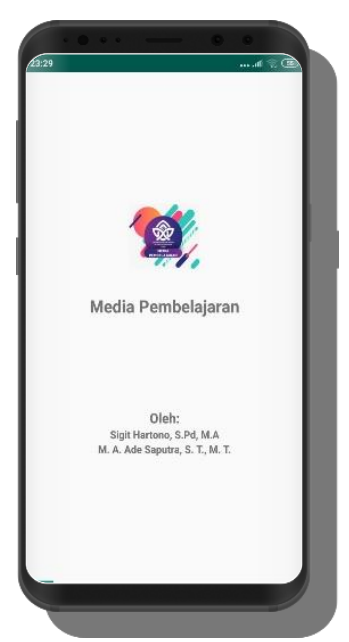

Gambar 1. Tampilan Awal

\section{Tampilan Log In}

Tampilan ini memuat alamat email atau NIM/NIP mahasiswa/dosen beserta password. Untuk dapat masuk keaplikasi ini mahasiswa harus melakukan Log In dengan mengisi email/username

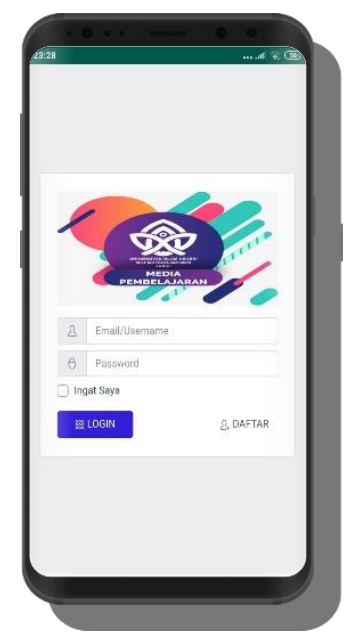

Gambar 1. Tampilan Login 
3. Tampilan Pendaftaran Akun

Jika mahasiswa atau dosen belum melakukan pendaftaran maka tidak dapat melakukan Log In. Oleh karena itu, mahasiswa terlebih dahulu harus mendaftar akun. Menu pendaftaran memuat status, email, nomor induk, nama lengkap, fakultas, program studi, dan kata sandi.

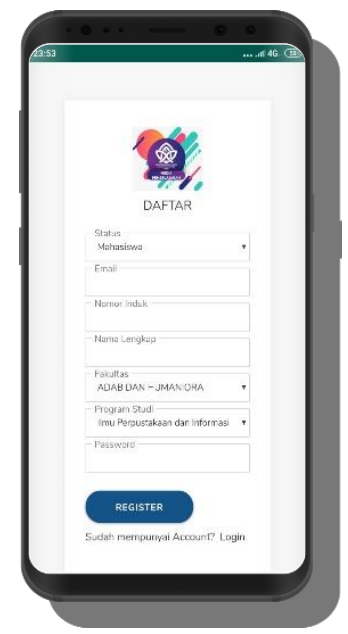

Gambar 2. Tampilan Pendaftaran Aku

4. Tampilan Menu Utama

Pada menu utama ini akan menampilkan pilihan menu yang dapat digunakan, antara lain menu untuk memasukkan kode kelas, daftar kelas yang diikuti mahasiswa, petunjuk penggunaan dan tentang kami.

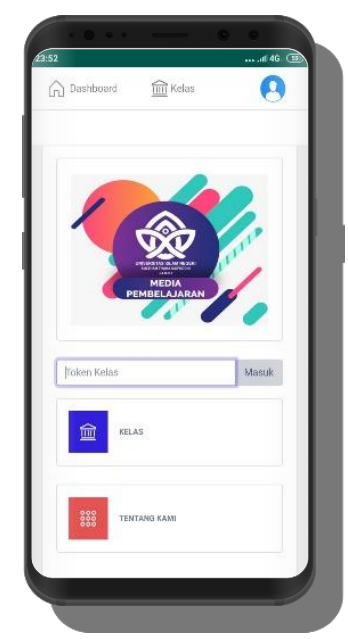

Gambar 3. Tampilan Menu Utama
5. Tampilan Menu Daftar Kelas

Pada menu daftar kelas ini akan menampilkan daftar kelas yang diikuti oleh mahasiswa,

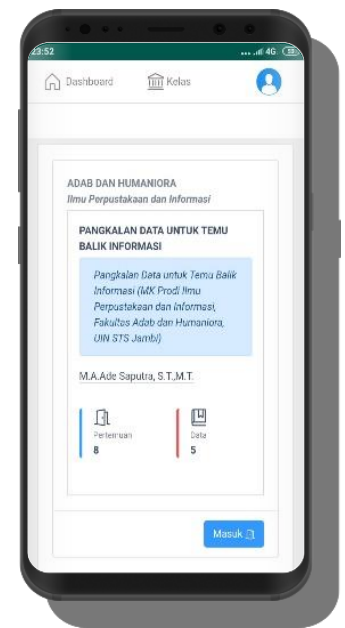

Gambar 4. Tampilan Menu Daftar Kelas

6. Tampilan Menu Kelas

Pada menu kelas akan menampilkan daftar pertemuan yang ada dalam kelas tersebut.

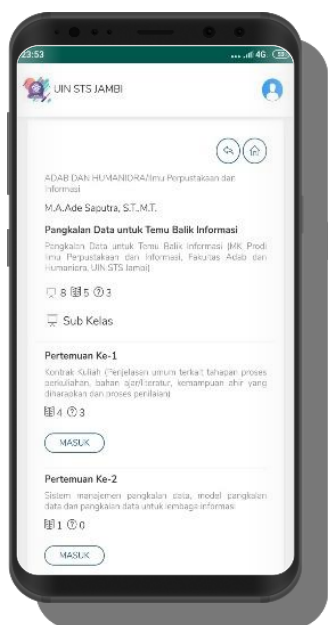

Gambar 5. Tampilan Menu Kelas

7. Tampilan Menu Pertemuan

Pada menu Pertemuan ini menampilkan isi dari materi dan soal latihan dari setiap pertemuan. 


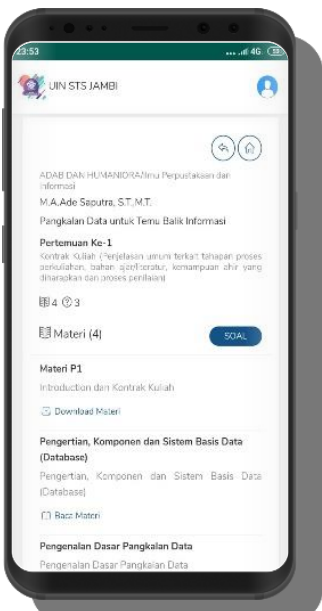

Gambar 6. Tampilan Menu Pertemuan

\section{Tampilan Menu Materi}

Pada menu daftar materi akan menampilkan daftar materi tiap pertemuan yang bisa diakses atau pun diunduh langsung oleh mahasiswa, selain itu juga terdapa tmateri perkuliahan berupa video yang dapat langsung dilihat oleh mahasiswa.
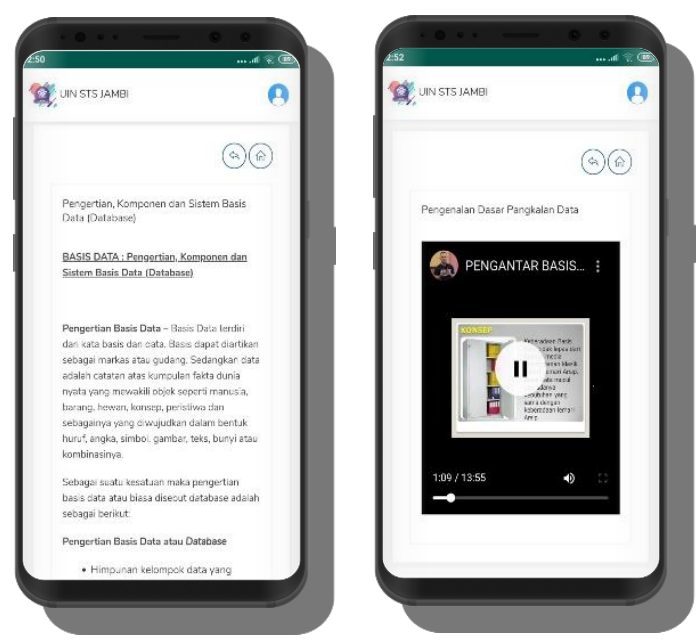

Gambar 7. Tampilan Menu Materi

\section{Tampilan Menu Soal}

Pada Menu Soal ini akan menampilkan daftar soal atau tugasyang akan dikerjakan oleh mahasiswa, pada menu ini terdapat dua jenis soal, yaitu soal pilihan ganda dan soal esai.
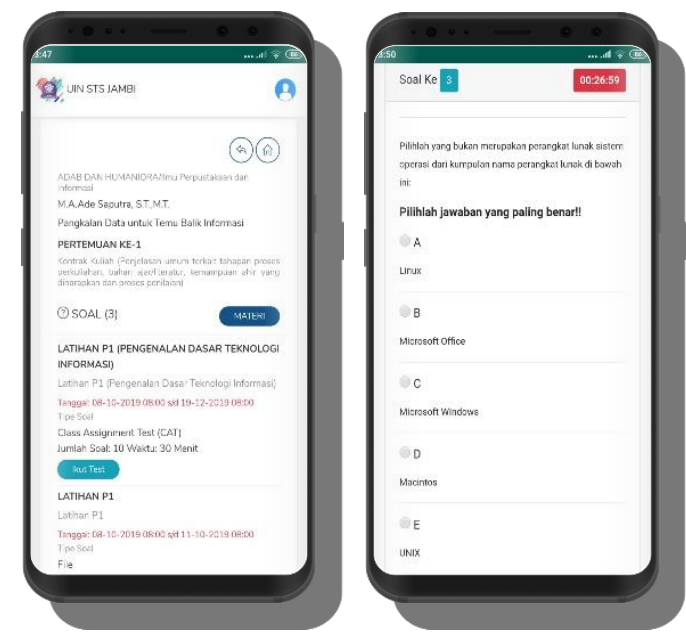

Gambar 8. Tampilan Menu Soal

\section{Tahapan Uji Coba}

Pada tahapan uji coba produk meliputi validasi dari ahli media, ahli materi, dan uji coba lapangan pada 40 orang mahasiswa Program Studi Ilmu Perpustakaan dan Informasi UIN STS Jambi. Tabel 1 merupakan hasil uji validasi ahli media. Di mana aplikasi mendapatkan total skor $94(83,92 \%)$ yang termasuk ke dalam kategori sangat layak.

Tabel 1. Hasil Uji Validasi Ahli Media

\begin{tabular}{clc}
\hline No & \multicolumn{1}{c}{ Aspek } & Nilai \\
\hline 1 & $\begin{array}{l}\text { Kaidah Media } \\
\text { Pembelajaran }\end{array}$ & 49 \\
2 & Desain & 45 \\
\hline Total & & $94(83,92 \%)$ \\
\hline Kategori & & SangatLayak \\
\hline
\end{tabular}

Di bawah in imerupakan tabe lhasil uji validasi oleh ahli materi di mana aplikasi ini mendapatkan total skor $64(84,21 \%)$ yang termasuk ke dalam kategori sangat layak.

Tabel 2. Hasil Uji ValidasiAhli Materi

\begin{tabular}{clc}
\hline \multicolumn{1}{c}{ No } & \multicolumn{1}{c}{ Aspek } & \multicolumn{1}{c}{ Nilai } \\
\hline 1 & Isi dan & 40 \\
& $\begin{array}{l}\text { Keseuaian } \\
\text { RPS }\end{array}$ & \\
2 & Tampilan & \multicolumn{1}{c}{24} \\
\hline Total & & $64(84,21 \%)$ \\
\hline Kategori & & $\begin{array}{l}\text { Sangat } \\
\text { Layak }\end{array}$ \\
& &
\end{tabular}


Di bawah ini merupakan tabel 3 hasil uji coba aplikasi kepada 40 orang mahasiswa Prodi Ilmu Perpustakaan dan Informasi. Aplikasi ini mendapatkan total skor 2347 (81,49\%) dengan kategori sangat layak.

Tabel 3. Uji Coba Mahasiswa

\begin{tabular}{ccc}
\hline No & Aspek & Nilai \\
& & \\
\hline 1 & Isi materi & 647 \\
2 & Tampilan & 1700 \\
\hline Total & & 2347 \\
& & $(81,49 \%)$ \\
\hline Kategori & & SangatLayak \\
\hline
\end{tabular}

\section{Pembahasan}

Berdasarkan hasil penelitian media pembelajaran berbasis android pada Prodi Ilmu Perpustakaan dan Informasi UIN Sultan Thaha Saifuddin Jambi telah berhasil dikembangkan dan mendapatkan penilaian yang layak dari ahli media dan materi. Selain itu, hasil uji coba lapangan yang telah dilakukan kepada 40 orang mahasiswa mendapatkan respon yang positif terhadap aplikasi tersebut. Sehingga, hal ini dapat disimpulkan bahwa aplikasi ini layak untuk digunakan baik oleh dosen ataupun mahasiswa sebagai media pembelajaran.

Hasil penelitian ini sejalan dengan penelitian yang dilakukan oleh Muyaroah \& Fajartia, (2017), Yektyastuti \& Ikhsan ( 2016), Oktarina, et.al., (2018) yang menunjukkan hasil bahwa media pembelajaran berbasis android layak dan dapat digunakan dalam kegiatan belajar mengajar. Dengan pemenafaatan media pembelajaran berbasis android ini juga dapat meningkatkan motivasi dan prestasi akademik mahasiswa. Hasil penelitian yang dilakukan oleh (Setyadi, 2017) menunjukkan bahwa game quiz berbasis android yang berhasil dikembangkan dapat memotivasi siswa dalam mengerjakan soal.

Media pembelajaran berbasis android merupakan media pembelajaran yang memanfaatkan teknologi sehingga dapat mengatasi keterbatasan ruang dan waktu di mana memungkinkan siswa belajar di mana pun berada(Astuti, Dasmo, \& Sumarni, 2017). Dengan adanya media pembelajaran ini memungkinkan mahasiswa untuk dapat mempelajari materi yang masih kurang dipahami kapan pun dan di mana pun.

Oleh karena itu, dengan adanya kemajuan teknologi dan tuntutan kebutuhan belajar peserta didik saat ini, tenaga pendidik diharapkan dapat mengembangkan media pembelajaran yang diminati oleh mahasiswa dan disesuaikan dengan karakteristik serta kebutuhan mahasiswa tersebut. Menurut Aripin (2018), terdapat beberapa perangkat dari mobile learning yang senantiasa dapat dikembangkan oleh tenaga pendidik seperti model drill and practice, model simulasi, model tutorial, serta model games.

Media pembelajaran berbasis android pada Prodi Ilmu Perpustakaan dan Informasi yang telah dikembangkan sedemikian rupa telah dirancang untuk dapat digunakan pada seluruh mata kuliah yang ada di Prodi Ilmu Perpustakaan dan Informasi. Sehingga, dosen maupun mahasiswa pada Prodi Ilmu Perpustakaan dan Informasi dapat menggunakan aplikasi ini yang dapat disesuaikan dengan kebutuhan dan capaian pembelajaran mahasiswa.

Walaupun terdapat sejumlah kelebihan dari media pembelajaran berbasis android, secara umum media pembelajaran berbasis android atau mobile learning juga memiliki sejumlah kekurangan diantaranya yaitu kemampuan prosesor yang dimiliki, kapasitas memori smartphone, tampilan layar, maupun operating system yang berbeda pada smartphone (Sarrab, Elgamel, \& Aldabbas, 2012)

Pada penelitian ini terdapat kekurangan yang ditemukan berupa aplikasi hanya dapat digunakan pada operating system berbasis android. Selain itu, aplikasi ini dapat dijalankan jika smartphone terhubung dengan internet. Kekurangan yang lain yang ditemukan pada aplikasi ini yaitu belum adanya 
BIP: Jurna Bahasa Indonesia Prima,

Vol 3, No. 1, 2021, Maret 2021, pp.

pembahasan terkait dengan jawaban pada soal-soal yang ada di aplikasi tersebut.

\section{E. Kesimpulan}

Media pembelajaran berbasis android yang telah dikembangkan oleh peneliti layak untuk digunakan. Namun, aplikasi ini juga masih memiliki sejumlah kekurangan. Diharapkan bagi peneliti selanjutnya dapat mengembangkan media pembelajaran yang digunakan pada lintas platform tidak sebatas pada android saja.

Daftar Pustaka

Amin, A. K., \& Mayasari, N. (2015). Pengembangan Media Pembelajaran Berbentuk Aplikasi Android. Magistra, (94).

Aripin, I. (2018). Konsep Dan Aplikasi Mobile Learning Dalam Pembelajaran Biologi. Bio Educatio, 3(April), 1-9.

Astuti, I. A. D., Dasmo, \& Sumarni, R. A. (2017). Pengembangan Media Pembelajaran Berbasis Android Pada Materi. Jurnal Pengabdian Kepada Maasyarakat, 24(May 2016), 695701.

https://doi.org/10.21831/jipi.v2i1.102 89

Borg, \& Gall. (2005). Educational Research: An Introduction (4th ed.). New York: Longman Inc.

Daryanto. (2010). Media Pembelajaran. Yogyakarta: Gava Media.

Hardianto, D. (2005). Media Pendidikan Sebagai Sarana Pembelajaran Efektif. Majalah Ilmiah Pembelajaran, 1(1), 95-104.

Muyaroah, S., \& Fajartia, M. (2017). Pengembangan Media Pembelajaran Berbasis Android dengan menggunakan Aplikasi Adobe Flash CS 6 pada Mata Pelajaran Biologi. Innovative Journal of Curriculum and Educational Technology, 6(2), 22-26. https://doi.org/10.15294/ijcet.v6i2.19 336

Nugroho, R. S., \& Purwandari, N. (2016). Implementasi Blended Learning Multimedia Berbasis Smartphone Untuk Pengayaan Pembelajaran Pada Sekolah XYZ. Jurnal Sains Dan Teknologi, 3(1), 37-48.

Oktarina, Y., Nurhusna, N., \& Saputra, M. A. A. (2018). Implementation of Blended Learning Through Smartphone-Based Applications in Disaster in Nursing Courses. Indonesian Nursing Journal of Education and Clinic (INJEC), 3(2), 113-121.

Purnama, R. B., Sesunan, F., \& Ertikanto, C. (2017). Pengembangan Media Pembelajaran Mobile Learning Berbasis Android Sebagai Suplemen Pembelajaran Fisika SMA Pada Materi Usaha dan Energi. Jurnal Pembelajaran Fisika, 5(4).

Sarrab, M., Elgamel, L., \& Aldabbas, H. (2012). Mobile Learning (MLearning) And Educational Environments. International Journal of Distributed and Parallel Systems (IJDPS), 3(4), 31-38. https://doi.org/10.1097/00152193198709000-00017

Setyadi, D. (2017). Pengembangan Mobile Learning Berbasis Android Sebagai Sarana Berlatih Mengerjakan Soal Matematika. Satya Widya, 33(2), 8792.

https://doi.org/10.24246/j.sw.2017.v3 3.i2.p87-92

Widyoko, E. P. (2011). Teknik Penyusunan Instrumen Penelitian. Yogyakarta: Pustaka Pelajar.

Yektyastuti, R., \& Ikhsan, J. (2016). Pengembangan Media Pembelajaran 
Berbasis Android pada Materi

Kelarutan untuk Meningkatkan

Performa Akademik Peserta Didik

SMA Developing Android-Based

Instructional Media of Solubility to

Improve Academic Performance of High School Students. Jurnal Inovasi

Pendidikan IPA, 2(1), 88-99. https://doi.org/10.21831/jipi.v2i1.102

89 